WORKING PAPER 1/2018

catedraempresafamiliar.webs2.uvigo.es/docs.html

March 2018

\title{
DO FAMILY FIRMS CONTRIBUTE TO JOB STABILITY? EVIDENCE FROM THE GREAT RECESSION
}

\author{
Santiago Lago-Peñas* \\ Alberto Vaquero-García* \\ Elena Rivo-López* \\ Mónica Villanueva-Villar**
}

*University of Vigo and GEN

**University of Vigo 


\title{
DO FAMILY FIRMS CONTRIBUTE TO JOB STABILITY? EVIDENCE FROM THE GREAT RECESSION
}

\author{
Santiago Lago-Peñas* \\ Elena Rivo López* \\ Alberto Vaquero García* \\ Mónica Villanueva Villar** \\ *University of Vigo and GEN \\ **University of Vigo
}

\section{ABSTRACT:}

This article analyzes if, on average, choices made by family businesses regarding job stability in bad times are different to those made by non-family firms. Moreover, we try to elucidate if this potential difference also depends on the family generation in charge. Our analysis relies upon a sample of 55,091 Spanish firms, Spain being one of the countries that suffered the greatest impact of the so-called "Great Recession". We find that at times of crisis, family businesses do maintain jobs in a higher extent than nonfamily businesses, and that this effect is especially intense when the first generation is in charge.

Keywords: family business, employment, generation, crisis, Socioemotional Wealth 


\section{Introduction}

This article aims to analyze whether, especially in bad times, family businesses behave differently to non-family businesses in terms of jobs stability. Also, we analyze if this behavior could depend on the generation that is in charge of the firm.

Like others on the role of generation in family businesses (Arrondo-García, Fernández-Méndez, \& Menéndez-Requejo, 2016; Zellweger, Kellermanns, Chrisman, \& Chua, 2012), our analysis is performed from the perspective of Socioemotional Wealth (SEW) (Berrone, Cruz, \& Gómez-Mejia, 2012; Chua, Chrisman, \& de Massis, 2015; Gómez-Mejía, Haynes, Núñez-Nickel, Jacobson, \& Moyano-Fuentes, 2007). SEW refers to "all non-financial aspects of the firm that meet the family's affective needs, such as identity, status, ability to examine influence, and perpetuation of the family dynasty" (Sciascia, Mazzola, \& Kellermanns, 2014, p. 132). Our main argument is that, because of their ownership and management characteristics, family businesses tend to maintain jobs at times of crisis in a higher extent than non-family businesses, even if turnover drops. This is because they try to protect their socioemotional wealth even at the cost of taking on greater risks (Gómez-Mejia et al., 2007). Insofar as we know that employment is very relevant for happiness of people ${ }^{1}$, job stability would be another contribution of family business to social welfare.

Overall, this effect depends on the history of the firm. Those run by the first generation, when ownership and management are more closely related and there are emotional links with employees, would maintain jobs more than those controlled by subsequent generations would. After the first generation, the family influence will be key for the firm's growth, stagnation or recession (Pieper, 2010). Hence, the later the generation, the more the family business is likely to behave like a non-family business in terms of employment.

\footnotetext{
${ }^{1}$ Although the analysis of happiness at work began with the contributions of Easterlin (1974), in the last two decades, researchers have attempted to assess how unemployment affects happiness of individuals. Di Tella, MacCulloh, \& Oswald (2011) conducted a study for 12 European countries; Clark and Oswald (1994) for the United Kingdom; Wolfers (2003) and Blanchflower, \& Oswald (2004) for the United Kingdom and the United States; in Germany, Winkelmann, 2014; for Japan, Ohtake (2012); Böckerman, \& Ilmakunnas (2005) for the case of Finland; De Neve, \& Ward (2017) worldwide. The bulk of this literature confirms that being employed involves a significant increase in happiness reported by individuals.
} 
To test our hypotheses, we built a database of 55,091 Spanish firms, 45,351 of them family and 9,740 non-family firms, for the period 2007-2015. The Spanish case is particularly interesting as it was one of the OECD countries mostly shocked by the “Great recession”. Our results confirm that family businesses tend to offer more stable employment than non-family businesses. However, this effect seems to fade with generational changes.

This study contributes to the research on family business in several ways. First, our study contributes to the literature on family business and employment from the SEW approach. Second, it also considers the generational effect on employment in a context of economic crisis ${ }^{2}$; nor has the moderating role of the generation in control been fully analyzed. Third, results grounds on sound econometric methodology applied using an extremely large database. In contrast with studies in the family business field that have typically focused on large listed firms (Mazzi, 2011), we rely upon a database of privately-held companies, which are more representative of family businesses in civil law countries such as Spain.

The article is structured as follows. After this introduction, the second section reviews the literature and develops the hypotheses. The third describes the research method, specifying how the data were collected, the variables and the econometric method used. The fourth section discusses the results. Finally, we draw some conclusions in section five.

\footnotetext{
${ }^{2}$ There have been very few studies on family business and employment in times of crisis (Backman \& Palmberg, 2015; Bjuggren, Johansson, \& Sjögren, 2011; Bjuggren, 2015; Block, Millán, Román, \& Zhou, 2015; Chen, Hou, Li, Wilson, \& Wu, 2014; Lee, 2006; Van Essen, Strike, Carney, \& Sapp, 2015).
} 


\section{Theoretical framework and hypotheses}

\subsection{Employment and crisis}

The Spanish case is of particular interest for analizing the effects of the "Great Recession”. Spain was one of the economies most deeply impacted by the crisis, in terms of both GDP (Figure 1) and employment (Figure 2). In particular, its unemployment rate rose to $26 \%$ (2012), more than any other advanced economy (Alvarez-Díaz, Caballero, Manzano, \& Martín-Moreno, 2015). Spain’s elasticity of unemployment to variations in GDP is the highest (2.0) among developed countries according to the IMF (2010). Similar results (1.98 for 2007-2009, and 2.1 for 2009-2014) (Table 1) were obtained from ILO-OECD-World Bank (2015). ${ }^{3}$.

[Figure 1 near here]

[Figure 2 near here]

[Table 1 near here]

\subsection{Family business, employment and crises}

The scarce international literature on the relationship between employment and family business tends to conclude that the latter offer stable employment at times of crisis. Unlike other companies, in situations of recession, family businesses allow greater involvement of workers in business operation (Siakas, Naaranoja, Vlachakis, \& Siakas, 2014), maintaining employment, even if profitability has to be sacrificed (Bjuggren, 2015). The relevant studies are presented below (Table 2).

Lee (2006) found, for the US and for the period 1992-2002, that family businesses had a positive impact on both employment and income growth and were more profitable than the non-family firms in Standard \& Poor's 500. Lee also shows that family businesses have a positive influence on employment stability in times of

\footnotetext{
${ }^{3}$ Pérez (2012) estimated that, between the first quarter of 2008 and the second of 2009, the elasticity of the unemployment rate with respect to Spanish GDP was 2.0. This result is significantly higher to elasticities computed for the whole Eurozone: (0.4), Netherlands (0.1) or Germany (0.0)
} 
recession. Along the same lines and for the period 2004-2009, Van Essen, Strike, Carney, \& Sapp (2015) indicate, with a sample from the EU27, that there are no significant differences in employment between family and non-family businesses in times of growth. However, family businesses are less likely to reduce levels of employment or wages in recessions or pre-crisis situations. Similarly, for Sweden for the period 1997-2009, Bjuggren (2015) found that family businesses were less sensitive to production levels and labor market fluctuations, which seems to correspond to extra labor protection in such businesses, especially during economic cycles. Finally, for 1994-2001, Block, Millán, Román, \& Zhou (2015) found that workers in family businesses in the EU15 enjoyed greater job stability, better job screening and more possibilities of promotion than those in non-family businesses, so they may be willing to accept lower remuneration than they would elsewhere.

Unlike the above, Backman \& Palmberg (2015) conclude that the differences between family and non-family businesses are minimal in relation to employment. They discuss the effects of governance and ownership of family businesses on employment in Austria and Hungary for the period 2008-2012.

From the SEW approach (Gómez-Mejia et al., 2007), the employees of family businesses feel closely identified with their employers and then attached to them, whether or not they are family members. Such attachments have a direct impact, providing non-economic benefits such as continuity and legacy (Chrisman, Chua, Pearson, \& Barnett, 2012) and retaining "workers in a certain community even though outsourcing would be more financially beneficial” (Astrachan \& Jaskiewicz, 2008). Since it is necessary for a family business to preserve its socioemotional wealth, such firms consider it necessary to maintain jobs during times of crisis because their workers are their main asset. We therefore pose the following hypothesis:

$\mathrm{H}_{1}$ : Family firm identification is positively associated with job stability during crisis periods 


\subsection{Family business, employment, crisis and generation}

Generational change in family businesses is considered a key process that sets them apart from non-family businesses (Chua, Chrisman, \& Sharma, 1999). With regard to employment, generational involvement may have a significant effect. In the first generation, it is the founder who controls the family firm and establishes very strong emotional ties with the next generation (Gersick, Davis, Hampton, \& Lansberg, 1997). The underlying idea is that the founder will pass the business on to his/her descendants. In addition, the importance of maintaining the firm's reputation and social identity will lead the founder to develop long-term relations with employees (Chen, Hou, Li, Wilson, $\& \mathrm{Wu}, 2014)$. Transgenerational control of the firm "is a primary driver of the socioemotional wealth perceptions of family firms’ owners” (Zellweger et al., 2012). When the next generation takes over, there is greater dispersion among shareholders, and the family firm starts to become similar to a non-family firm because ownership and control are no longer solely in the hands of the founder. As the generations change, family firms seem to be more interested in making a profit than in maintaining jobs. That is, socioemotional wealth seems to be stronger during the first generation and is weakened as the generations change and family ownership becomes diluted (GómezMejia et al., 2007). It is therefore of interest to analyze how family succession affects employment.

We consider that the generational stage of a family firm in crises will have a negative impact on employment, that is, a family firm will try to survive by restructuring its staff, and this process will become more intense with successive generations. We therefore pose the following hypothesis:

$\mathrm{H}_{2}$ : The later the generation in control of the FB, the less likely it will be to maintain jobs during crisis periods.

[Table 2 near here] 


\section{Data and method}

\subsection{Sample and data}

To analyze the impact of the economic crisis on employment in family and nonfamily firms in Spain, we use the SABI-Amadeus database for the period 2006-2015. ${ }^{4}$ We selected the sample (Table 3) based on the following criteria: i) legal form, considering only corporations or limited liability companies; (ii) active in 2015; (iii) annual turnover exceeding EUR 2 million or staff of 10 or more employees; (iv) complete information throughout the period studied and for all the variables. After these filters, the final sample comprised 55,091 enterprises (45,351 family firms and 9,740 non-family firms, according to the classification of the Family Business Institute).

[Table 3 near here]

\subsection{Variables}

Taking into account the models used in the literature (Lee, 2006; Chen et al., 2014; Backman \& Palmberg, 2015; Bjuggren, 2015; Van Essen et al., 2015), as the dependent variable we use annual relative variation in employment, based on information taken from SABI. As independent variables, we include the rate of annual change in sales lagged by one period and the family nature of the firm: we define a dummy variable coded 1 in the case of family business and 0 otherwise, based on the criterion established by the Family Business Institute (2015). As context variables, we consider two sets of dummy variables, REGION and SECTOR. While the former includes the 17 Spanish regions and two autonomous cities, the latter captures the sector group from CNAE2009 classification (21 in total). ${ }^{5}$ For family firms only, we create a set of dummy variables (GEN1, GEN2, GEN3), for the generation currently in charge of the firm, calculated by estimating a generational change every 30 years, in line with Cabrera-Suárez \& MartínSantana $(2013)^{6}$. The first generation represents $79 \%$ of all family firms, the second $20 \%$

\footnotetext{
${ }^{4}$ The SABI-Amadeus database contains financial information from 2 million Spanish companies for financial analysis.

${ }^{5}$ CNAE: Acronym of National Classification of Economic Activities in Spain.

${ }^{6}$ More specifically, dummy variable GENt is coded 1 for observations corresponding to the $t$ generation of family firms and 0 otherwise.
} 
and the third and following 1\%. Finally, we considered firm size, establishing four categories, based on Cucculelli \& Storai (2015): less than 50 employees; from 50 to 99; 100 to 249 and 250 and over. Table 4 contains the description of the variables and data sources.

[Table 4 near here]

\subsection{Descriptive analyses}

Table 5 reports the descriptive statistics of the variables used. The initial sample included a number of outliers and far outliers. Hence, database filtering was necessary for consistency. Given the large number of observations, this did not reduce statistical representativeness. Table 6 shows the outlier elimination process. The initial sample had 495,819 observations over the period 2007-2015. Applying the boxplot method over the initial sample, we detected 105,367 outlier observations (21\% of the total). We performed double elimination using the sales variable (lagged by one year) and the variation in employment. The final sample contains 390,452 valid observations.

[Table 5 near here]

[Table 6 near here]

\subsection{Econometric model}

Several preliminary tests on the inclusion of both individual and period effects showed their relevance. Furthermore, a Hausman test revealed that the hypothesis of no correlation between individual effects and regressors should be ruled out and that fixed effects are a better option than random effects. However, including fixed effects makes it impossible to estimate the effect of time-invariant or mostly time-invariant variables (family, size, region and sector) due to multicollinearity. For this reason and to check the robustness of results, we alternatively estimated the specification including individual fixed effects and excluding time-invariant regressors and vice versa. In order to test the influence of potential cross-equation contemporaneous correlation as well as different 
error variances in each cross-section, we report the t-statistic using both Panel Least Squares (PLS) standard errors and White-type robust cross-section standard errors.

According to our specification, the effect of family business on employment can be twofold. First, the employment variable aims to capture if variation in employment growth was significantly different in family firms. Second, we include one interaction, FAMILY-SALES $_{\mathrm{t}-1}$, to compare the effect of changes in sales during the previous year on the variation in employment in both family and non-family firms. According again to the specification, the coefficient for variable SALES $S_{t-1}$ would be $\beta_{2}$ for non-family firms and $\beta_{2}+\beta_{3}$ for family firms. Hence, if $\beta_{3}$ were 0 , then the coefficient for both groups of firms would be the same. The use of lagged values for SALES $t-1$ prevents a potential problem of simultaneity or endogeneity in estimates.

The specification also includes the control variables: firm size, two sets of dummies to control for sector and region, and the fixed-period effects. The general specification to be estimated is the following (equation 1):

$$
\begin{aligned}
\mathrm{E}_{\mathrm{it}}=\alpha_{\mathrm{i}}+\lambda_{\mathrm{t}}+\beta_{0} & +\beta_{1} \cdot \text { FAMILY }_{\mathrm{i}}+\beta_{2} \cdot \text { SALES }_{\mathrm{it}-1}+\beta_{3} \cdot \text { FAMILY }_{\mathrm{i}} \cdot \text { SALES }_{\mathrm{it}-1}+ \\
& +\sum_{\mathrm{j}} \delta_{\mathrm{j}} \cdot \text { REGION }_{\mathrm{j}}+\sum_{\mathrm{k}} \gamma_{\mathrm{k}} \cdot \text { SECTOR }_{\mathrm{k}}+\varepsilon_{\mathrm{it}}
\end{aligned}
$$

For family firms only, we add a second specification which includes a set of dummies to measure the effect of generation on employment. In order to avoid perfect

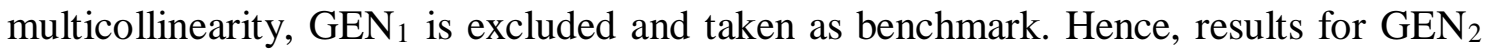
and $\mathrm{GEN}_{3}$ should be interpreted as the differential effects with respect to firstgeneration firms. Terms including variable family are set aside insofar as non-family firms are excluded from the econometric analysis.

$$
\mathrm{E}_{\mathrm{it}}=\alpha_{\mathrm{i}}+\lambda_{\mathrm{t}}+\beta_{0}+\beta_{1} \cdot \mathrm{SALES}_{\mathrm{it}-1}+\sum_{\mathrm{j}} \delta_{\mathrm{j}} \cdot \mathrm{REGION}_{\mathrm{j}}+\sum_{\mathrm{k}} \gamma_{\mathrm{k}} \cdot \mathrm{SECTOR}_{\mathrm{k}}+\sum_{\mathrm{l}} \eta_{\mathrm{l}} \cdot \mathrm{GEN}_{\mathrm{l}}+\varepsilon_{\mathrm{it}}
$$




\section{Results}

Table 7 summarizes the econometric results. In column 1a, individual fixed effects are excluded. In column 1b, time-invariant or mostly invariant variables are dropped. Results using PLS standard errors or robust errors are similar. Variables are highly significant in all cases. Autocorrelation is not a serious concern. Regressing residuals on lagged residuals yielded a common coefficient close to zero $(\hat{\rho}=-0.03)$ in column 1. This coefficient is larger in absolute value in column $1 \mathrm{~b}(\hat{\rho}=-0.18)$ but it is still low. With both $T<10$ and $\rho<|0.3|$, PLS is as good as or better than the usual generalized estimators (Griliches \& Rao, 1969). In any case, in order to check the robustness of our results, in column 1c we re-estimate the specification in column 1b using Non Linear Least Squares (NLLS) to correct for AR(1) autocorrelation. ${ }^{7}$ Results hold across columns.

In column 1a, the coefficient for FAMILY is positive and significant, meaning that the evolution of employment in family firms was clearly more positive (or less negative). On average, the annual employment variation rate was $0.31 \%$ higher.

As expected, jobs dynamics is directly related to sales. The average elasticity of employment to sales in non-family firms ranges from 0.147 in column 1 a to 0.093 in column 1b. Moreover, this elasticity tends to be significantly lower in the case of family firms. The coefficient of SALES $\mathrm{t}_{\mathrm{t}-1}$ is 0.128 for family firms in column $1 \mathrm{a}$, and 0.074 in column 1b. Job stability over the economic cycle is higher in family firms. On average, it is around $15 \%$ higher. Moreover, the evolution of employment was better in the case of younger and bigger firms. Finally, while results for both sets of regional and sectoral dummies are significant, the latter are much more relevant than the former.

In column 2, we added the generation effect with the dummy variables $\mathrm{GEN}_{2}$ and $\mathrm{GEN}_{3}$. Results show that firms tend to be less committed to maintaining employment with generational change.

[Table 7 near here]

\footnotetext{
${ }^{7}$ Period effects are dropped from column 1c due to econometric reasons. Moreover, the need to use lagged values reduces the sample size, due to the loss of the first observation and gaps in the database where observations are missing.
} 
The results conform to the protectionist model of employment, according to which employment fluctuations are smoothed out in this type of company, indicating that family firms ensure more stable employment than non-family firms do. These results are similar to those obtained in the international literature (Backman \& Palmberg, 2015; Bjuggren, 2015; Chen et al., 2014; Lee, 2006; Van Essen et al., 2015).

In addition, our estimates are consistent with the arguments held by the European Parliament. In particular, the Report on Family Companies in Europe (European Parliament, 2015) and the opinion of the European Economic and Social Committee (2016) indicate that family firms have a high degree of social responsibility, with their employees contributing to the creation and maintenance of jobs. This study provides the first econometric approach to the role of family businesses in employment during the worst economic crisis that Spain has suffered in recent years. Although there have been some studies published by the Network of Chairs of Family Business, they mostly provide descriptive contents. There have been no econometric studies on this topic in the Spanish case. We hope this article will expand knowledge on the important role of family firms in employment.

\section{Discussion and conclusions}

Our findings lead to three main conclusions. Firstly, family firms destroyed less employment than non-family firms did during the crisis insofar as they are less sensitive to changes in sales. According to the SEW approach, the emotional links between ownership and management make the firm more prudent when hiring during good times and when firing in times of crisis. This makes employment in family businesses more stable than in private ones. This result involves two positive effects. A higher job stability is an additional contribution of family firms to social welfare and happiness. And a larger share of family firms would involve stronger automatic macro-stabilizers to deal with the business cycle, supplementing fiscal macro-stabilizer such as the Personal Income Tax (PIT) or the unemployment insurance.

Secondly, when we focus on family firms, the positive effect of the family on employment is more intense when the firm is under the control of the first generation, 
and it fades as the generations change. Our results are in line with those by Lee (2006), who did not analyze generational change but did consider firm age, obtaining a negative and significant relation between this variable and the level of employment. So, the older the firm, the higher the probability of firing workers. This result differs from that obtained by Kellermans, Eddelston, Barnett, \& Pearson (2008) who found a positive and significant relation between the family generation and growth in employment.

Our study extends previous research by analyzing the relation between family firm and employment at times of crisis, but also includes the generation effect by applying the SEW approach. Our results are in line with those by Sciascia et al. (2014, p. 135) who argued that "at late generational stages, family members identify less with the firm and are less emotionally attached, as different family branches pursue their respective needs, agendas and commitment”. That is, as the generations change, the search for SEW decreases.

In summary, this research contributes to the family business literature by examining the relation between family business and employment during a crisis period, considering differences based on the generation in control. Our findings encourage researchers to incorporate the socioemotional wealth perspective and the moderating role of the generational stage in their empirical research. 


\section{REFERENCES}

Alvarez-Díaz, M., Caballero, G., Manzano, B., \& Martín-Moreno, J.M. (2015). Assessment of Political Situation over the Business Cycle in Spain: A time Series Analysis. Hacienda Pública Española / Review of Public Economics, 213: 41-62.

Arrondo-García, R., Fernández-Méndez, C., \& Menéndez-Requejo, S. (2016). The growth and performance of family Business during the global financial crisis: The role of the generation in control. Journal of Family Business Strategy, 7: 227-237.

Astrachan, J.H., \& Jaskiewicz, P. (2008). Emotional returns and emotional costs in privately held family businesses: advancing traditional business valuation, Family Business Review, XXI (2): 139-149.

Backman, M., \& Palmberg, J. (2015). Contextualizing small family firms: How does the urban-rural context affect firm employment growth? Journal of Family Business Strategy, 6: 247-258.

Bank of Spain (2011). Annual Report, Madrid.

Berrone, P., Cruz, C., \& Gomez-Mejia, L.R. (2012). Socioemotional wealth in family firms: theoretical dimensions, assessment approches, and agenda for future research. Family Business Review, 25 (3): 258-279.

Bjuggren, C.M. (2015). Sensitivity to shocks and implicit employment protection in family firms. Journal of Economic Behavior \& Organization, 119: 18-31.

Bjuggren, C.M., Johansson, D., \& Sjögren, H. (2011). A Note on Employment and Gross Domestic Product in Swedish Family-Owned Businesses: A Descriptive Analysis. Family Business Review, 24(4): 362-371.

Blanchflower, D.G., \& Oswald A.J. (2004). "Well-being over time in Britain andthe USA”, Journal of Public Economics, 88 (7): 1359-86.

Block, J.H., Millán, J.M., Román, C., \& Zhou, H. (2015). Job satisfaction and wages of family employees. Entrepreneurship Theory and Practice, march: 183-207. 
Böckerman, P., \& Ilmakunnas, P. (2005). Elusive effects of unemployment on happiness, Social Indicators Research, 79 (1): 159-169.

Cabrera-Suárez, K., \& Martín-Santana (2013). Top management teams and performance in non-listed family firms. Journal of Management \& Organization, 19: 405-423.

Chrisman, J., Chua, J., Pearson, A., \& Barnett, T. (2012). Family involvement, family influence and family-centered non-economic goals in small firms. Entrepreneurship: Theory \& Practice, 36 (2): 267-293.

Chen, Q., Hou, W., Li, W., Wilson, C., \& Wu, Z. (2014). Family Control, Regulatory Environment, and the Growth of Entrepreneurial Firms: International Evidence. Corporate Governance: An International Review, 22(2): 132-144.

Chua, J.H., Chrisman, J.J., \& Sharma, P. (1999). Defining the family business by behavior. Entrepreneurship Theory and Practice, 23 (4): 19-39.

Chua, J.H., Chrisman, J.J., \& de Massis, A. (2015). A Closer Look at Socioemotional Wealth: Its Flows, Stocks, and Prospects for Moving Forward. Entrepreneurship: Theory \& Practice: $173-182$.

Clark, A.E., \& Oswald, A.J. (1994). "Unhappiness and unemployment”, The Economic Journal, 104 (424): 648-59.

Cucculelli, M., \& Storai, D. (2015). Family firms and industrial districts: Evidence from the Italian manufacturing industry”. Journal of Family Business Strategy, 6(4): 234246.

De Neve, J. \& Ward, G. (2017). Happiness at Work. Saïd Business School WP 2017-07.

Di Tella, R., MacCulloch, R.J., \& Oswald, A.J. (2001). "Preferences over inflation and unemployment: Evidence from surveys of happiness”, American Economic Review, 91(1): 335-41.

Easterlin, R.A. (1974): "Does economic growth improve the human lot? Some empirical evidence" in David y Reder (eds) Nations and households in economic growth: 89-125, Elsevier. 
European Parliament (2015). Report on Family Companies in Europe. $\quad$ http://www.europarl.europa.eu/sides/getDoc.do?pubRef=//EP//TEXT+REPORT+A8-2015-0223+0+DOC+XML+V0//EN

Eurostat (2017). Labour force statistics, http://www.oecd.org/std/labour-stats/

Gersick, K.E., Davis, J.A., Hampton, M., \& Lansberg, I. (1997). Generation to generation: life cycles of the family Business. Harvard Business School Presss, Boston.

Gómez-Mejía, L.R., Haynes, K.T., Núñez-Nickel, M., Jacobson, K.J., \& MoyanoFuentes, J. (2007). Socioemotional wealth and business risks in family-controlled firms: Evidence from Spanish olive oil mills. Administrative science quarterly, 52(1): 106137.

Griliches, Z., \& Rao, P. (1969). Small simple properties of several two stage regression methods in the context of autocorrelated errors. Journal of the American Statistical Association, 64, 253-272.

IMF (2010). "Unemployment Dynamics during Recessions and Recoveries: Okun's Law and Beyond”, chapter 3 World Economic Outlook.

Family Business Institute (2015). La empresa familiar en España. Cátedra de Empresa Familiar, Barcelona.

Kellermans, F.W., Eddelston, K.A., Barnett, T., \& Pearson, A. (2008). An exploratory study of family member characteristics and involvement: Effects on entrepreneurial behavior in the family firm, Family Business Review, 21 (1): 1-14.

Lee, J. (2006). Family Firm Performance: Further Evidence. Family Business Review, 19 (2): 103-114.

Mazzi, Ch. (2011). Family Business and Financial Performance: Current State of Knowledge and Future Research Challenges, Journal of Family Business Strategy 2(3): 166-181.

OECD 
ILO-OECD-World Bank (2015). G20 Labour Markets in 2015: Strengthening the Link between growth and employment, https://www.oecd.org/g20/topics/employment-andsocial-policy/G20-Labour-Markets-in-2015-Strengthening-the-Link-between-Growthand-Employment.pdf

Ohtake, F. (2012). “Unemployment and Happiness”, Japan Labor Review, 9(2), Spring. Pieper, T.M. (2010). Non solus: Toward a psychology of family business, Journal of Family Business Strategy, 1: 26-39.

Sciascia, S., Mazzola, P., \& Kellermanns, F. (2014). Family management and profitability in private family-owned firms: Introducing generational stage and the socioemotional wealth perspective. Journal of Family Business Strategy, 5: 131-137

Siakas, K., Naaranoja, M., Vlachakis, S., \& Siakas, E. (2014). Family Business in the New Economy: How to Survive and Develop in Times of Financial Crisis. Procedia Economics and Finance, 9: 331-341.

Van Essen, M., Strike, V.M., Carney, M., \& Sapp, S. (2015). The resilient family firm: Stakeholder outcomes and institutional effects. Corporate Governance: An International Review, 23(3): 167-183.

Winkelmann, R. (2014). Unemployment and hapiness. Successful policies for helping the unemployed need to confront the adverse effects of unemployment on feelings of life satisfaction, IZA World of Labor No. 94.

Wolfers, J. (2003). "Is business cycle volatility costly? Evidence from surveys of subjective well-being”, Working Paper No. 9619, National Bureau of Economic Research, Cambridge, MA.

Zellweger, T.M., Kellermanns, F.W., Chrisman, J.J., \& Chua, J.H. (2012). Family control and family firm valuation by family CEOs: The importance of intentions for transgenerational control. Organization Science, 23(3): 851-868. 
Figure 1: Annual growth rates of GDP in Spain, EU28, Eurozone19 and OECD34 (2005-2016)

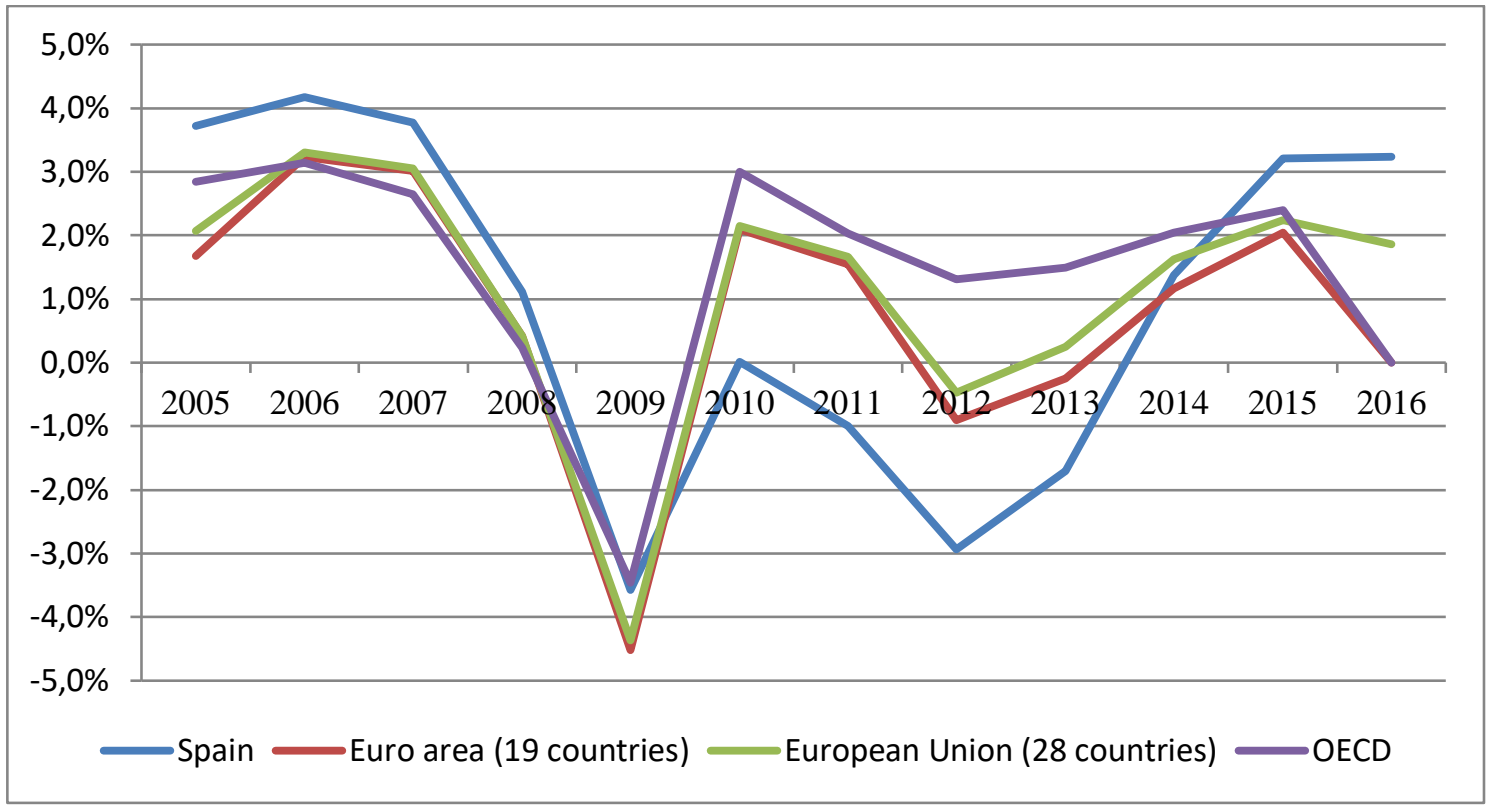

Source: National Accounts, Eurostat (2017) and OECD (2017)

Figure 2: Evolution of the rate of unemployment in Spain, Eurozone19, EU28 and OECD34 (2005-2016)

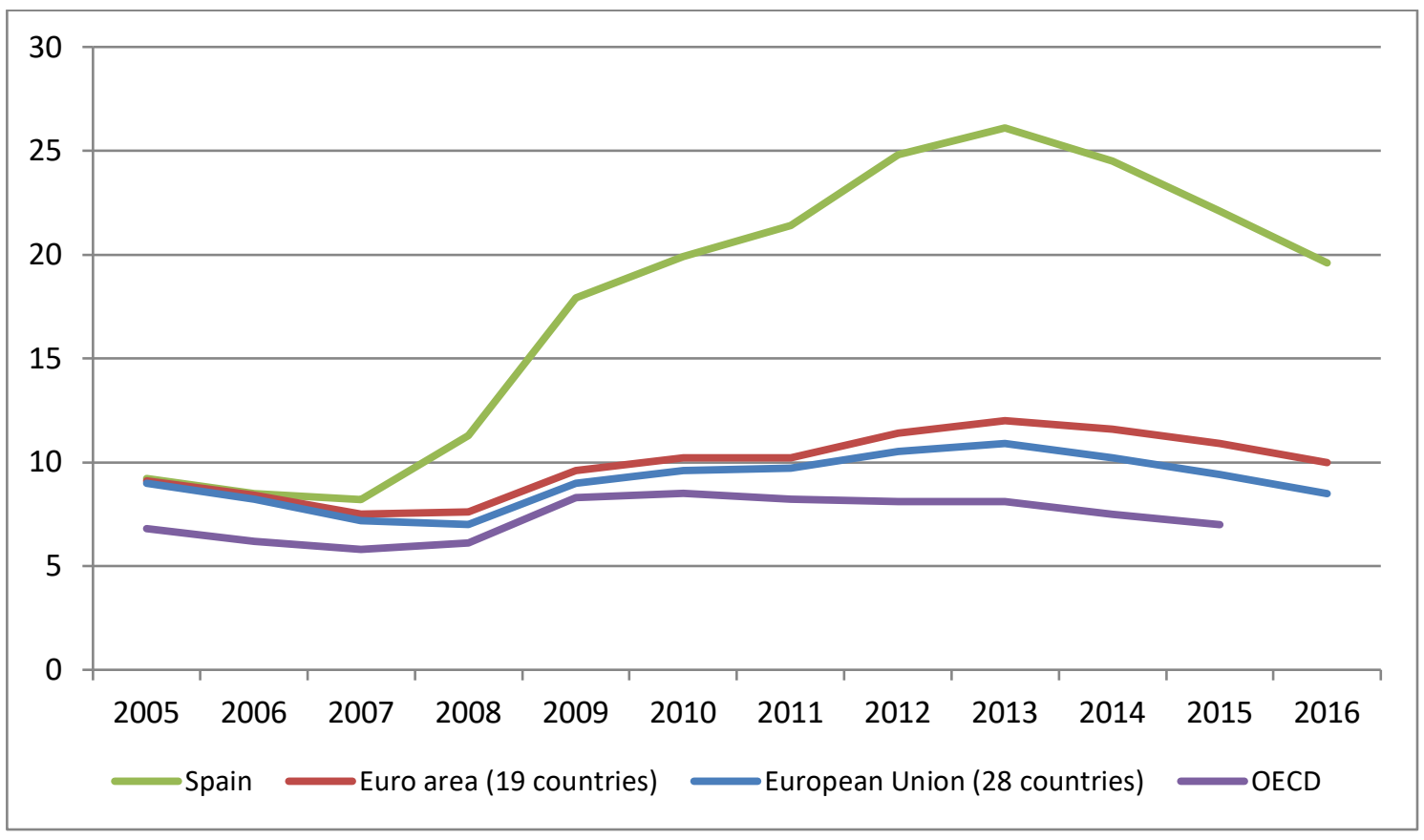

Source: Eurostat (2017) and OECD (2017). Values in percentage. 
Table 1: Country-level employment elasticities and GDP growth rates (1999-2014)

\begin{tabular}{|l|c|c|c|c|c|c|}
\hline & \multicolumn{7}{|c|}{} & & \\
\hline & $1999-2007$ & $2007-2009$ & $2009-2014$ & $1999-2077$ & $2007-2009$ & $2009-2014$ \\
\hline Spain & 1.02 & 1.98 & 2.01 & 3.8 & -1.3 & -0.5 \\
\hline Greece & 0.24 & 0.14 & 0.93 & 4.1 & -2.4 & -4.9 \\
\hline Italy & 1.2 & 0.21 & 0.40 & 1.5 & -3.3 & -0.5 \\
\hline Portugal & 0.28 & 0.92 & 0.94 & 1.5 & -1.4 & -1.0 \\
\hline Germany & 0.3 & -0.07 & 0.43 & 1.6 & -2.4 & 1.9 \\
\hline United Kingdom & 0.29 & 0.31 & 0.54 & 3.0 & -2.3 & 1.7 \\
\hline Netherlands & 0.52 & 0.06 & -0.52 & 2.3 & -0.6 & 0.3 \\
\hline
\end{tabular}

Source: ILO-OECD-World Bank (2015). G20 Labour Markets in 2015: Strengthening the link between growth and employment 
Table 2: Overview of the international economic literature on family business and employment (2006-2015)

\begin{tabular}{|c|c|c|c|c|c|c|}
\hline Authors & Years of Study & Country & Data Source & Variables & Methodology & Results \\
\hline $\begin{array}{l}\text { Lee } \\
\text { (2006) }\end{array}$ & $1992-2002$ & $\begin{array}{l}\text { United } \\
\text { States }\end{array}$ & $\begin{array}{l}\text { List of S\&P 500. Sample: } \\
403 \text { firms. }\end{array}$ & $\begin{array}{l}\text { Dependent variable (alternative measures of firm } \\
\text { performance): employment growth, revenue } \\
\text { growth, gross income (before taxes) growth and net } \\
\text { profit margin. } \\
\text { Independent variables (alternative measures of } \\
\text { family influence, stakes held by founding family } \\
\text { members, etc.), SIC Codes } \\
\text { Control variables: size, growth opportunities, age } \\
\text { of firm, incentive to perform better }\end{array}$ & $\begin{array}{l}\text { Multivariate regression with cross- } \\
\text { sectional data. }\end{array}$ & $\begin{array}{l}\text { In recession, family firms may suffer as } \\
\text { much as other firms but are less likely to lay } \\
\text { off employees. }\end{array}$ \\
\hline $\begin{array}{l}\text { Bjuggren, } \\
\text { Johansson } \\
\text { and } \\
\text { Sjögren } \\
\text { (2011) }\end{array}$ & 1993-2006 & Sweden & $\begin{array}{l}\text { Data from Statistics } \\
\text { Sweden covering all firms } \\
\text { with employees: } 440,000 \\
\text { firms. Panel of data } \\
\text { contains 5,496,177 } \\
\text { observations. }\end{array}$ & No econometric model & Descriptive & $\begin{array}{l}\text { A large proportion of the total increase in } \\
\text { employment was in family firms. } \\
\text { Family firms in Sweden make a marked } \\
\text { contribution to employment and GDP. }\end{array}$ \\
\hline $\begin{array}{l}\text { Chen, } \\
\text { Hou,Li, } \\
\text { Wilson } \\
\text { and Wu } \\
\text { (2014) }\end{array}$ & 2000 & $\begin{array}{l}80 \\
\text { countries }\end{array}$ & $\begin{array}{l}\text { Data from the World } \\
\text { Business Environment } \\
\text { Survey } 2000 \text { conducted by } \\
\text { the World Bank. Sample } \\
\text { using information from } \\
6,950 \text { firms in } 80 \text { countries } \\
\text { and one territory, drawn } \\
\text { from the WBES. }\end{array}$ & $\begin{array}{l}\text { Business growth measured in two ways: } \\
\text { employment growth and sales growth. } \\
\text { Dependent variable: growth in the number of } \\
\text { employees (over the past three years) } \\
\text { Independent variables: family firm (or family } \\
\text { group), quality of a country's regulatory } \\
\text { environment (seven indicators), size, age of firm, } \\
\text { difficulty of obtaining information on laws and } \\
\text { regulations. Five dummy variables capture industry } \\
\text { effects }\end{array}$ & Regression analysis. & $\begin{array}{l}\text { Family firms tend to have lower sales } \\
\text { growth, but higher employment growth. } \\
\text { Family firms' growth strategies are much } \\
\text { more sensitive to a country's external } \\
\text { governance mechanisms than those of non- } \\
\text { family firms }\end{array}$ \\
\hline $\begin{array}{l}\text { Backman } \\
\text { and } \\
\text { Palmberg } \\
(2015)\end{array}$ & $\begin{array}{l}2013 \text { (telephone } \\
\text { interview), but the } \\
\text { dependent variable } \\
\text { was growth in } \\
\text { employment from } \\
2008 \text { to } 2012\end{array}$ & Sweden & $\begin{array}{l}580 \text { firms with 1-49 } \\
\text { employees }\end{array}$ & $\begin{array}{l}\text { Dependent variable: change in employment } \\
\text { between 2008-2012 } \\
\text { Independent variables: firm type, number of years } \\
\text { since firm was registered, number of employees } \\
\text { and several dummies for SIC code, municipal level } \\
\text { (metro, urban, rural) and interaction variables }\end{array}$ & $\begin{array}{l}\text { They extended the framework } \\
\text { constructed by Evans (1987a, 1987b). } \\
\text { OLS regression analysis }\end{array}$ & $\begin{array}{l}\text { Being a family firm does not influence } \\
\text { employment growth, unless the activity takes } \\
\text { place in a rural area. } \\
\text { Positive employment growth in rural } \\
\text { locations in family firms is a result of the } \\
\text { strong influence of social capital and local } \\
\text { embeddedness of family firms. Family firms } \\
\text { are more attached to the region in which they } \\
\text { are located. }\end{array}$ \\
\hline $\begin{array}{l}\text { Bjuggren } \\
\text { (2015) }\end{array}$ & $1997-2009$ & Sweden & $\begin{array}{l}\text { Data from Statistics } \\
\text { Sweden on all firms with } \\
\text { at least five employees. } \\
757,719 \text { observations }\end{array}$ & $\begin{array}{l}\text { Dependent variable: natural logarithm of } \\
\text { employment in firm sales. } \\
\text { Independent variables: natural logarithm of total } \\
\text { sales or value added in industry minus the } \\
\text { contribution of specific firm and year dummies, } \\
\text { elasticity to industry shocks and elasticity to } \\
\text { economy-wide shocks. }\end{array}$ & $\begin{array}{l}\text { Method proposed by Guiso et al (2005), } \\
\text { and One-step first-differenced GMM } \\
\text { (Generalized Method of Moments) by } \\
\text { Arellano and Bond (1991). Panel data to } \\
\text { control for covariates and fixed effects. }\end{array}$ & $\begin{array}{l}\text { Employment in family firms is less sensitive } \\
\text { to performance and product manager } \\
\text { fluctuations. } \\
\text { Family firms are more cautious when hiring } \\
\text { and firing. The employees of family firms } \\
\text { have implicit job protection. }\end{array}$ \\
\hline
\end{tabular}




\begin{tabular}{|c|c|c|c|c|c|c|}
\hline $\begin{array}{l}\text { Block, } \\
\text { Millán, } \\
\text { Román } \\
\text { and Zhou } \\
\text { (2015) }\end{array}$ & $1994-2001$ & EU-15 & $\begin{array}{l}\text { Data from ECHP } \\
\text { (Eurostat) that is, a } \\
\text { standardized, } \\
\text { representative annual } \\
\text { survey conducted at the } \\
\text { level of the EU-15. Final } \\
\text { data set comprises 149,889 } \\
\text { observations (from } \\
46,780 \text { individuals) over } \\
\text { the period 1994-2001, } \\
\text { including 2,861 } \\
\text { observations (1,257 } \\
\text { individuals) from family } \\
\text { firm employees. }\end{array}$ & $\begin{array}{l}\text { Dependent variables: job satisfaction index and log } \\
\text { (monthly wage). } \\
\text { Focal independent variable: family employee. } \\
\text { Control variables: family aspects, socioeconomic } \\
\text { characteristics, job characteristics and business } \\
\text { sector, country and year dummies. }\end{array}$ & Fixed-effects panel data regressions. & $\begin{array}{l}\text { Family employees gain additional utility } \\
\text { from working in their family business and } \\
\text { are willing to accept lower wages in } \\
\text { exchange for this additional utility. } \\
\text { Family employees exhibit higher levels of } \\
\text { job satisfaction with lower wages. }\end{array}$ \\
\hline $\begin{array}{l}\text { Van } \\
\text { Essen, } \\
\text { Strike, } \\
\text { Carney } \\
\text { and Sapp } \\
\text { (2015) }\end{array}$ & $2004-2009$ & $\begin{array}{l}27 \\
\text { European } \\
\text { countries }\end{array}$ & $\begin{array}{l}\text { Data set of } 2,949 \text { firms. } \\
\text { Manual collection of data } \\
\text { plus digital sources } \\
\text { including Datastream, } \\
\text { MINT Global/ORBIS, } \\
\text { Thomson One Banker, and } \\
\text { Worldscope. }\end{array}$ & $\begin{array}{l}\text { Dependent variables: firm performance (cumulative } \\
\text { market-adjusted stock returns); employee outcomes } \\
\text { with two measures: workforce decrease and wage } \\
\text { reduction. } \\
\text { Independent variables: family firms, anti-self- } \\
\text { dealing index, employee protection, rule of law. } \\
\text { Control variables: firm, size, industry concentration } \\
\text { (Herfindahl index), debt, capital asset pricing } \\
\text { model, market risk, return on assets (ROA) and } \\
\text { industry dummies. }\end{array}$ & $\begin{array}{l}\text { Hierarchical linear modeling (HLM). } \\
\text { Hierarchical structure with two levels, } \\
\text { each of which is represented by its own } \\
\text { regression equation. } \\
\text { Model 1, firm-specific variables. Model } \\
\text { 2, country-specific variables }\end{array}$ & $\begin{array}{l}\text { Family firms financially outperform non- } \\
\text { family firms during the financial crisis but } \\
\text { show no significant differences during the } \\
\text { stable-growth period between } 2004 \text { and } \\
2006 \text {. }\end{array}$ \\
\hline
\end{tabular}

Source: Authors's elaboration. 
Table 3: Database building process

\begin{tabular}{|l|c|}
\hline & Total firms \\
\hline Firms available in SABI & $2,400,779$ \\
\hline Legal form (S.A. or S.L.) & $1,483,581$ \\
\hline Active in 2015 & 786,460 \\
\hline Minimum size ( $>$ 2M€ in sales or $>10$ employees) & 118,932 \\
\hline Information available (years and variables) & 55,091 \\
\hline Family firms & 45,351 \\
\hline Non-family firms & 9,740 \\
\hline
\end{tabular}

Table 4: Description of variables and sources

\begin{tabular}{|l|l|l|}
\hline Variable & Definition & Source \\
\hline Dependent variable & \multicolumn{2}{|l|}{} \\
\hline E & $\begin{array}{l}\text { Variation in employment (expressed in } \\
\text { percentage) }\end{array}$ & SABI Database \\
\hline Independent variables & $\begin{array}{l}\text { Dummy variable coded 1 for family firms and 0 } \\
\text { otherwise. }\end{array}$ & $\begin{array}{l}\text { Institute of Family } \\
\text { Business }\end{array}$ \\
\hline FAMILY & Relative rate of change in sales. Lagged one year & SABI Database \\
\hline SALES-1 & $\begin{array}{l}\text { Four groups by number of employees: } \\
\text { SIZE }\end{array}$ & $\begin{array}{l}\text { Cucculelli, M. \& Storai, } \\
\text { D. (2015) }\end{array}$ \\
& $\begin{array}{l}\text { - Less than 50 } \\
\text { - } 100 \text { to } 99\end{array}$ & \\
\hline GEN & $\begin{array}{l}\text { Family generation in family firms. } \\
-\quad \text { GEN1 - Aged from 1 to 30 (in 2015) }\end{array}$ & Cabrera-Suárez \& \\
& $\begin{array}{l}\text { Martín-Santana (2013) } \\
\text { - GEN2 - Aged from 31 to 60 (in 2015) }\end{array}$ & \\
\hline
\end{tabular}

Table 5: Descriptive statistics

\begin{tabular}{|l|c|c|c|c|c|}
\hline & Mean & Median & Maximum & Minimum & Std. Dev. \\
\hline E & -0.78 & 0.00 & 32.97 & -32.98 & 11.73 \\
\hline FAMILY & 0.82 & 1.00 & 1.00 & 0.00 & 0.38 \\
\hline SALES-1 & 0.33 & 0.37 & 38.26 & -36.58 & 15.00 \\
\hline SIZE & 1.29 & 1.00 & 4.00 & 1.00 & 0.72 \\
\hline Observations: 390,452 & & & & & \\
\hline
\end{tabular}

Table 6: Outliers

\begin{tabular}{|l|l|}
\hline Phase & Observations \\
\hline Initial Data & 495,819 \\
\hline Outliers & $105,367(21 \%)$ \\
\hline Final Data & 390,452 \\
\hline
\end{tabular}


Table 7: Estimates of specifications [1] and [2]

\begin{tabular}{|c|c|c|c|c|}
\hline & 1a & 1b & 1c & 2 \\
\hline FAMILY & $\begin{array}{c}0.331 \\
(6.46)^{* * *} \\
{[4.7]^{* * *}} \\
\end{array}$ & & & \\
\hline SALES $_{-1}$ & $\begin{array}{c}0.147 \\
(49.6)^{* * *} \\
{[21.4]^{* * *}}\end{array}$ & $\begin{array}{c}0.093 \\
(28.6)^{* * *} \\
{[11.8]^{* * *}}\end{array}$ & $\begin{array}{c}0.132 \\
(34.4)^{* * *} \\
{[10.2]^{* * *}}\end{array}$ & $\begin{array}{c}0.127 \\
(88.2)^{* * *} \\
{[16.2]^{* * *}}\end{array}$ \\
\hline FAMILY*SALES $_{-1}$ & $\begin{array}{c}-0.019 \\
(6.03)^{* * *} \\
{[4.42]^{* * *}}\end{array}$ & $\begin{array}{c}-0.019 \\
(5.26)^{* * *} \\
{[4.76]^{* * *}}\end{array}$ & $\begin{array}{c}-0.012 \\
(2.97)^{* * *} \\
{[2.04]^{* *}}\end{array}$ & \\
\hline SIZE & $\begin{array}{c}0.557 \\
(20.5)^{* * *} \\
{[8.87]^{* * *}} \\
\end{array}$ & & & $\begin{array}{c}0.856 \\
(23.3)^{* * *} \\
{[9.36]^{* * *}}\end{array}$ \\
\hline GEN2 & & & & $\begin{array}{c}-1.019 \\
(20.1)^{* * *} \\
{[9.96]^{* * *}}\end{array}$ \\
\hline GEN3 & & & & $\begin{array}{c}-1.436 \\
(7.34)^{* * *} \\
{[5.47]^{* * *}}\end{array}$ \\
\hline AR(1) & & & -0.18 & \\
\hline $\mathbf{R}^{2}$ & 0.056 & 0.206 & 0.256 & 0.056 \\
\hline $\begin{array}{c}\text { Number of } \\
\text { observations }\end{array}$ & 390,452 & 390,452 & 297,642 & 321,464 \\
\hline Autocorrelation & -0.03 & -0.18 & & -0.04 \\
\hline $\begin{array}{l}\text { Fixed effects } \\
\text { specification }\end{array}$ & $\begin{array}{l}\text { Only period } \\
\text { fixed effects }\end{array}$ & $\begin{array}{l}\text { Both individual } \\
\text { and period fixed } \\
\text { effects }\end{array}$ & $\begin{array}{l}\text { Only individual } \\
\text { fixed effects }\end{array}$ & $\begin{array}{l}\text { Only period } \\
\text { fixed effects }\end{array}$ \\
\hline Estimator & PLS & PLS & NLLS & PLS \\
\hline
\end{tabular}

Notes: [1] Standard t-statistics in parenthesis and white-type cross-section robust t-statistics in brackets. ***, **, and $*$ mean statistical significance at $1 \%, 5 \%$ and $10 \%$, respectively. Results for individual effects, regional dummies, and sectoral dummies are not reported in the Table. Estimates performed using Eviews 10+. Estimate in column 2 only includes observations for family firms. PLS means Panel Least Squares. NLLS in the acronym for Non-Linear Least Squares. 